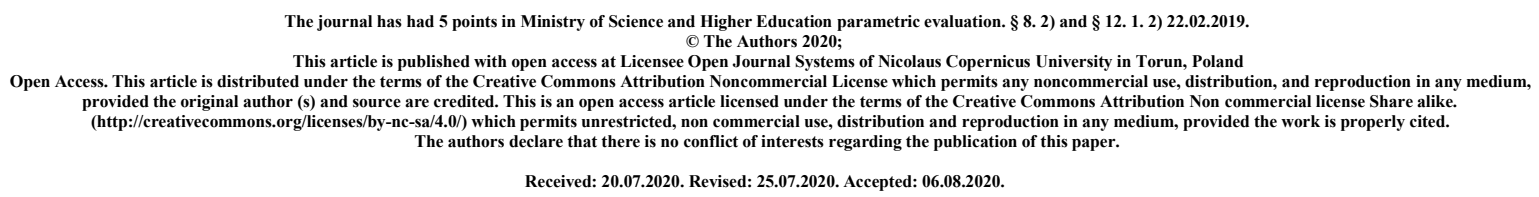

\title{
Adipose tissue and its proinflammatory properties
}

\author{
Waldemar Pluta, Aleksandra Radecka, Wioleta Dudzińska, Anna Lubkowska \\ Department of Functional Diagnostics and Physical Medicine, Pomeranian Medical \\ University in Szczecin, Żołnierska 54 Str., 71-210 Szczecin, Poland
}

\begin{abstract}
For many years, adipose tissue was considered only as an energy store, additionally having an insulating and protective function against injuries. The discovery of the $o b$ gene more than 20 years ago meant that adipose tissue is now seen as an endocrine gland regulating / modulating the body's energy metabolism, inflammatory and immune processes thanks to the secretion of bioactive molecules such as adipokines, enzymes, hormones and growth factors. The substances secreted by adipose tissue with a pro-inflammatory effect include, among others leptin, resistin, tumor necrosis factor, lipocalin 2, angiopoietin-like protein, interleukin-6, interleukin-18, visfatin, monocyte chemotactic factor 1 , chemerin or a plasminogen activator inhibitor.
\end{abstract}

KEY WORDS: adipose tissue, immunology, inflammation 


\section{INTRODUCTION AND PURPOSE}

Adipose tissue is responsible for the accumulation of fat, which is a reserve material for energy production [1]. Additionally, it acts as an endocrine organ. Compared to other endocrine organs, it is scattered throughout the body [2]. The main mass of adipose tissue are fat cells - adipocytes, whose primary function is the storage of TAGs, which are the body's main energy reserve material. There are also pre-adipocytes, a subpopulation of stem cells (SVF cells), fibroblasts, macrophages, leukocytes and endothelial cells in adipose tissue [3, 4]. The purpose of the study was to present the current state of knowledge about the structure, functions and activities of adipose tissue with a special focus its proinflammatory activity. The selection of publications from 2000-2020 was made on the basis of the PubMed, ResearchGate and Google Scholar databases, using the following keywords: "adipose tissue", "visceral adipose tissue", "pro-inflammatory properties", "adipokines".

\section{DESCRIPTION OF THE STATE OF KNOWLEDGE}

\section{Characteristics of adipose tissue}

Adipose tissue can be divided into white (or yellow; WAT) and brown (BAT). White adipose tissue occurs in all mammals and consists mainly of adipocytes $20-200 \mu \mathrm{m}$ in size, $90-99 \%$ are triglycerides (TAG), the rest are fatty acids (FA), diglycerides, monoglycerides, cholesterol, phospholipids [2]. In women, WAT accumulates mainly subcutaneously in the area of the hips and thighs (gynoid type), while in men, in the abdominal area (android type). Its excessive distribution is associated with numerous metabolic diseases, e.g. type 2 diabetes and diseases of the cardiovascular system. The increase in the concentration of PUFA derived from WAT lipid vesicles causes an increase in glucose released from the liver and the production of very low density lipoproteins (VLDL).

Brown adipose tissue owes its name to the macroscopically visible brown color. Microscopically, a dense network of capillaries and a large intracellular accumulation of mitochondria are observed. Characteristic features include the presence of numerous cytosolic reservoirs containing fat [1]. BAT occurs in rodents and in primates early in life. BAT was thought to only occur in newborns and to decrease over time and to disappear completely in adulthood. However, studies have shown its presence also in adults [5, 6]. Cypess et al. [7], apart from identifying active BAT cells in adults, showed that in people over 65 years of age the number of active BAT cells is inversely proportional to BMI. Unlike white adipose tissue, BAT is related to gender (more women), body weight, and age. Brown adipocyte adipocytes are more dispersed within the medium and the cell sizes are much smaller. BAT in humans occurring mainly in the subcutaneous tissue of the interscapular region, mediastinum, along the nerve bundle of the neck, in the armpit, around the kidneys and adrenal glands [1]. Only $30-50 \%$ of the cell volume is made up of lipids, which accumulate as small droplets. Its increased distribution in newborns and children up to 10 years of age is associated with the immaturity of the mechanisms of thermogenesis regulation. Brown adipose tissue is characterized by richer sympathetic innervation and the presence of a specific mitochondrial system in which the specific UCP-1 uncoupling protein is involved.

Tissues are also functionally different: the primary function of white tissue is lipid metabolism, which means uptake from blood, lipogenesis, energy storage in the form of 
TAGs and lipolysis, and release of PUFA into the blood as the body's metabolic needs. The brown tissue utilizes lipids which generate energy. The thermogenic properties of BAT are presumed to influence the metabolism of TAGs by reducing excess fat accumulation. This, in turn, reduces the risk of obesity and type 2 diabetes. This remarkable ability of BAT to burn fat may be used in the future in the fight against obesity and the metabolic syndrome $[1,4,8$, 9].

Table 1. Differences in the structure and functions of WAT and BAT [2, 8, 9].

\begin{tabular}{|c|c|}
\hline WAT & BAT \\
\hline is found in all mammals & $\begin{array}{l}\text { occurs in rodents and primates (most } \\
\text { of it in the initial period of life) }\end{array}$ \\
\hline adipocyte size: $20-200 \mu \mathrm{m}$ & adipocyte size: $20-40 \mu \mathrm{m}$ \\
\hline $\begin{array}{l}\text { TAG accumulated in } 1 \text { follicle, } \\
\text { which increases with their } \\
\text { accumulation, pushing the cell } \\
\text { organelles to the cell periphery }\end{array}$ & $\begin{array}{l}\text { TAG accumulates in many vesicles, } \\
\text { which facilitates access to } \\
\text { compounds during thermogenesis }\end{array}$ \\
\hline $\begin{array}{l}\text { a few mitochondria of oblong shape } \\
\text { and small diameter }\end{array}$ & $\begin{array}{l}\text { numerous mitochondria of spherical } \\
\text { shape and large diameter, numerous } \\
\text { cytochromes giving the tissue color }\end{array}$ \\
\hline $\begin{array}{l}\text { the presence of a thermogenin } \\
\text { protein in the inner membrane of } \\
\text { mitochondria }\end{array}$ & lack of thermogenin \\
\hline $\begin{array}{l}\text { adrenergic terminals mainly around } \\
\text { blood vessels }\end{array}$ & $\begin{array}{l}\text { adrenergic terminals around blood } \\
\text { vessels and directly on cells }\end{array}$ \\
\hline fewer adrenergic endings & higher number of adrenergic endings \\
\hline less vascular & $\begin{array}{l}\text { very richly vascularized, high blood } \\
\text { flow }\end{array}$ \\
\hline $\begin{array}{l}\text { no relationship between body fat } \\
\text { content and gender, age and body } \\
\text { weight }\end{array}$ & $\begin{array}{l}\text { the amount of tissue depends on sex, } \\
\text { age and body weight }\end{array}$ \\
\hline $\begin{array}{l}\text { increased distribution is associated } \\
\text { with metabolic diseases and } \\
\text { problems with the cardiovascular } \\
\text { system }\end{array}$ & $\begin{array}{l}\text { increased distribution is associated } \\
\text { with immaturity of the thermogenesis } \\
\text { regulatory mechanism }\end{array}$ \\
\hline $\begin{array}{l}\text { main function: accumulation of the } \\
\text { energy substrate in the form of TAG }\end{array}$ & main function: heat generation \\
\hline
\end{tabular}

Due to its location, there is abdominal (visceral, internal) and subcutaneous fat. The cells of these tissues differ not only in size but also in functionality. Visceral adipose tissue is considered to be the main source of adverse metabolic changes.

As a result of the release of adipokines, PUFA and glycerol directly into the portal circulation, the hepatic insulin clearance is reduced, gluconeogenesis is increased, and the production of TAG and apolipoprotein-B in the liver is increased. 
Due to the produced pro-inflammatory substances, adipocytes increase the production of Creactive protein and promote the development of non-alcoholic fatty liver disease. Visceral adipose tissue produces more biologically active compounds, e.g. adiponectin, resin, visfatin, TNF $\alpha$, PAI, IL-6, subcutaneous tissue, in turn, is characterized by a higher concentration of leptin [10].

Subcutaneous adipose tissue is characterized by the ability to produce unique, typical adipokines. Adipokines affect the function of adjacent tissues and organs, including kidneys, heart, bone marrow, blood vessels and lungs. Most adipokines are pro-inflammatory. Their concentration is increased in obese people, which makes them an important factor promoting the development of metabolic diseases [11].

\section{Pro-inflammatory properties of adipose tissue}

For many years, adipose tissue has been perceived as an energy store, with an additional insulating and protective function against injuries. Discovery of the $o b$ gene and its product leptin [12] - caused adipose tissue to be seen as an endocrine gland regulating / modulating the body's energy metabolism, inflammatory and immune processes due to the secretion of bioactive molecules such as adipokines, enzymes, hormones and growth factors.

One theory of increased inflammatory activation in obesity is that it results from the combination of the adipose tissue properties of macrophages and adipocytes and their mutual influence on activity through the release of pro-inflammatory cytokines and lipids. Gene expression in both types of these cells is very similar. Many proteins are expressed in adipocytes that are specific for macrophages, such as IL-6, matrix metalloproteinases (MMPs), and TNF- $\alpha$. On the other hand, macrophages express most genes that are characteristic of adipocytes, incl. $\gamma$-peroxisome proliferation activating receptor (PPAR $\gamma$ ). Adipocytes and macrophages also show functional similarities. Macrophages show a predisposition to lipid storage by macrophages, which leads to the formation of foam cells. In turn, adipocytes exhibit the ability to phagocytosis and bactericidal properties, thanks to which, in the right environment, they can differentiate into macrophages.

An interesting hypothesis was put forward by Trayhurn et al. [13], according to which the inflammatory reaction in adipose tissue is a response to hypoxia of enlarged adipocytes distant from the vessels. This hypothesis was confirmed in experimental studies carried out on the cultures of murine and human adipocytes. It has been proven that hypoxia may be a factor stimulating the secretion of some adipokines, including leptin, a factor that inhibits macrophage migration, and IL-6. Hypoxia caused an inflammatory response of macrophages in adipose tissue and inhibition of the differentiation of prediapocytes into adipocytes.

Experimental studies were also carried out to assess the possible effect of infection on inflammatory activation taking place in fat cells. The subject of the research was the culture of human adipocytes infected with cytomegalovirus, adenoviruses subtype 2 and 36, influenza A virus and Chlamydia pneumonia. In the supernatants of infected and uninfected cells, the concentration of adiponectin, TNF- $\alpha$, IL-6 and plasminogen activator inhibitor 1 (PAI-1) was tested after 48 hours.

There was an increase in IL-6 concentration due to infection with adenovirus subtype 36 and cytomegalovirus, while in the case of TNF- $\alpha$, none of the factors influenced the concentration of the compound [14]. 
There are many studies that have proven a relationship between increased inflammatory activation in obesity and the development of insulin resistance.

The inflammatory response in obesity is believed to be a homeostatic mechanism that prevents the body from reaching points where excess fat accumulation impairs mobility. On the other hand, in the course of inflammatory processes caused by infection, catabolic processes are triggered, which result in the release of lipids stored in adipose tissue. Catabolic processes activated by inflammation in obesity may be an attempt to inhibit further weight gain [15]. Experimental studies confirm the hypothesis [16, 17]. Local inflammation and insulin resistance in adipose tissue in TNF transgenic mice and mice with defective peripheral TNF receptors have been shown to be metabolically beneficial (lean phenotype and peripheral insulin sensitivity). Stress in the endoplasmic reticulum is one of the mechanisms leading to an increase in inflammatory activation in obesity. Tissue cultures and animal studies have provided information that this type of stress is increased primarily in adipose tissue, which undergoes architectural remodeling when lipid and protein synthesis is increased and the balance between intracellular nutrients is disturbed. Changes in cell metabolism are the result of the activation of NF- $\kappa \mathrm{B}$ and pp38 mitogenically activated protein kinase, as well as JNK and IKK kinases (nuclear factor modulator $\kappa \mathrm{B}$ ), which in turn increases the expression of cyclooxygenase 2 . In turn, activation of NF- $\kappa \mathrm{B}$ stimulates the production of pro-inflammatory substances such as TNF- $\alpha$ and IL-6.

The pro-inflammatory cascade can also be activated as a result of oxidative stress. Its increase is caused by an increased supply of glucose to adipose tissue, where it is taken up by the endothelial cells of the stromal vessels, which increases the production of free radicals in the vascular endothelium. Free radicals damage the endothelium and activate the proinflammatory cascade. Endothelial damage in adipose tissue may cause macrophages to migrate to adipose tissue, which results in exacerbation of the local inflammatory process. Increased glucose concentration also increases the production of free radicals in adipocytes, resulting in the production of pro-inflammatory cytokines by these cells [15].

\section{Substances secreted by adipose tissue with a pro-inflammatory effect Leptin}

Leptin is a protein anorexigenic hormone with a mass of $16 \mathrm{kDa}$, the function of which is to adjust the amount of consumed food to the content of adipose tissue. It is produced mainly by adipose tissue, but small amounts are produced by skeletal muscles, placenta, stomach and in the central nervous system [10]. The increase in plasma concentration of this hormone is proportional to the increase in adipose tissue mass, and it decreases with the loss of body weight and with the use of a low-fat diet. Membrane receptors are located in the central nervous system in the hypothalamus, in particular around the arcuate nucleus, the choroid plexus of the brain, and in peripheral tissues such as the adrenal glands, thyroid, ovaries, testes, placenta and prostate. In skeletal muscles, leptin increases GLUT-4 translocation to the cell membrane surface, stimulates glucose uptake and glycogen synthesis. The effect of this hormone on the metabolism of muscle lipids is antagonistic to that of insulin.

As for adipose tissue, the action of leptin is also opposite to insulin, and additionally reduces lipogenesis and intensifies lipolysis. The secretion of the hormone is regulated by the circadian rhythm - the greatest secretion is observed between 10 p.m. and 3 a.m. - which 
results in the cessation of food intake during sleep. This substance additionally affects the body processes such as blood pressure, hematopoiesis or processes related to the reproductive system. Attempts have been made to use the hormone in anti-obesity therapy, but it turned out to be ineffective. This is due to the presence of leptin resistance, which is likely due to impeded passage of leptin across the blood-brain barrier and / or inhibition of the intracellular leptin signaling pathway.

Leptin has an immunomodulatory effect on the acquired and innate immune response. Increases the secretion of Th1-dependent cytokines (IL-2, IFN- $\gamma$ ) while inhibiting the release of Th2-dependent cytokines (IL-4), promoting the differentiation of naive T cells towards Th1 lymphocytes $[10,18,19]$. Leptin enhances the proliferation and activity of human CD4 + and $\mathrm{CD} 8+\mathrm{T}$ cells through leptin receptors present in the plasma membrane. The observation of Saucillo et al. [20] showed a close correlation between the state of hunger, accompanied by low blood leptin concentration, and the impaired function of activated $\mathrm{T}$ lymphocytes manifested by decreased synthesis of pro-inflammatory cytokines. The defect of activated $\mathrm{T}$ lymphocytes was due to decreased expression of the GLUT4 glucose transporter and its decreased uptake. Leptin is involved in the regulation of the innate immune response by influencing the number and activity of macrophages and granulocytes. It stimulates macrophages to synthesize chemokines CCL3, CCL4, CCL5, and monocytes to produce TNF- $\alpha$ and IL-6. In addition, it plays a role in stimulating the secretion of free radicals in monocytes and in increasing the proliferation and migration of these cells. Synthesized proinflammatory factors (such as TNF- $\alpha$ ) increase the concentration of the hormone in the blood and adipose tissue, which results in the intensification of the already existing inflammation [11].

\section{Resistin}

Resistin is a $12 \mathrm{kDa}$ protein rich in cysteine, which is associated with the activation of inflammatory processes [19]. Human resistin is produced mainly by cells of the immune system: macrophages, monocytes, peripheral blood inflammatory cells and leukocytes [21]. In addition, resistin expression has been detected in the spleen, bone marrow, skeletal muscle, thymus, stomach, pancreatic islets, small intestine, placenta and uterus. Resistin gene transcription (RETN) is induced by the pro-inflammatory cytokines TNF- $\alpha$, IL-1 and IL-6. Although resistin was discovered in 2001, its receptor has still not been identified. Only a few of the molecules involved in resistin signal transduction are known. Since this protein has many functions, it is supposed that it does not have one type of receptor, but several types, including the Toll-like receptor 4 (TLR4). The physiological role of resistin is to maintain glycemia during starvation, while the pathological effect is associated with the induction of insulin resistance, resulting in excess body fat. A close relationship has been proven between the concentration of resistin and the degree of insulin resistance. In addition, this protein is involved in the development of inflammation and inflammatory diseases (including arthritis or atherosclerosis), the regulation of lipid and carbohydrate metabolism, and the stimulation of endothelial cell proliferation.

The direct effect on adipose tissue manifests itself in the regulation of adipocyte proliferation and differentiation. Resistin attenuates the anti-inflammatory effect of adiponectin on vascular endothelial cells by stimulating the expression of adhesion molecules, vascular cell adhesion 
molecule (VCAM-1), intercellular adhesion molecules 1 (ICAM-1) and pentraxin 3 which are involved in leukocyte adhesion. Metabolic and hormonal factors are responsible for the secretion and concentration of resistin. Obese people have higher protein levels than lean people. When you are full, your resistin levels are higher than when you are starving [22]. Also, hyperglycaemia increases the concentration of resistin in the blood plasma [11,23].

\section{Tumor necrosis factor (TNF- $\alpha$ )}

TNF- $\alpha$ is a pro-inflammatory cytokine and is produced, inter alia, by by macrophages and monocytes. It plays a significant role in the development of inflammation of various origins [11]. In adipose tissue, it inhibits the activity of genes related to the metabolism of fatty acids and glucose and a decrease in the secretion of certain adipokines, including the antiinflammatory adiponectin, which has a negative impact on insulin resistance. TNF- $\alpha$ stimulates the production of pro-inflammatory IL-6. In addition, this factor activates sphingomyelinases - enzymes that are responsible for the formation of ceramide due to the hydrolysis of sphingomyelin, a sphingolipid found in the cell membrane. Intracellular accumulation of ceramide is associated with the induction of muscle insulin resistance [18]. Studies have shown that TNF- $\alpha$ lowers the ability of adipose tissue to accept and esterify fatty acids from circulating lipoproteins as a result of lowering the activity of enzymes involved in this process, including Glyceraldehyde-3 dehydrogenase (GAPDH), acetyl-coenzyme A carboxylase, fatty acid synthase or lipoprotein lipase. It is also known that TNF- $\alpha$ stimulates lipolysis by increasing the activity of the hormone-dependent lipase. These processes result in an increase in PUFA concentration and a decrease in glucose consumption. Tumor necrosis factor has been shown to have a direct effect on islet $\beta$ cells by inhibiting preproinsulin transcription and insulin secretion. TNF- $\alpha$ induces oxidative stress by increasing the activity of nitric oxide synthase (iNOS), resulting in an increase in NO production. The increase of these 2 compounds leads to a decrease in the amount of IRS- 1 and consequently to the inhibition of insulin action. iNOS also leads to the formation of ROS, which increases the activity of the nuclear factor NF-kB. TNF- $\alpha$ additionally increases insulin resistance by increasing the concentration of resistin and lowering the expression of PPAR- $\gamma$ receptors $[11$, $15]$.

\section{Lipocalin 2 (LCN2)}

Lipocalin 2 is a $25 \mathrm{kDA}$ protein belonging to the superfamily of lipocalin proteins which bind and transport low molecular weight lipophilic substances, e.g. arachidonic acid, retinoids and steroids. In humans, it is present in the form of storage monomers in neutrophils, where they are heterodimerized $[11,24]$. LCN2 acts as a pleiotropic mediator of various inflammatory processes and is involved in the transport of iron to the cytoplasm. It is involved in apoptosis and innate immunity [25]. It promotes host resistance to pathogens by binding bacterial siderophores (chemicals that chelate iron ions), which in turn inhibits the production of IL-10 by macrophages. Macrophage inactivation worsens some infections, such as pneumococcal pneumonia [26].

LCN2 expression is stimulated by various inflammatory stimuli, incl. NF-kB, lipopolysaccharide and IL-1. In humans, the concentration of LCN2 in the blood serum is closely related to anthropometric and biochemical variables. Positive correlations with fasting 
glycaemia, the HOMA-IR index of insulin resistance and the level of C-reactive protein are observed. These relationships exist even after correcting the BMI, suggesting that LCN2 is an independent risk factor for insulin resistance, diabetes and inflammation. Lipocalin-2 induces its side effects, at least in part, by activating the metabolic pathway of arachidonate 12lipoxygenase and stimulating the expression of TNF- $\alpha$ in adipose tissue, which in turn may increase local inflammation and worsen energy homeostasis and systemic insulin resistance [27].

\section{Angiopoietin-like protein (ANGPTL2)}

Angiopoietin 2 belongs to the angiopoietin-like family, a family of eight (ANGPTL1-8) members of glycoproteins [28]. The presence of angiopoietin-like protein was found in blood plasma and adipocytes. This protein promotes insulin resistance and the development of inflammation. Diet-induced obesity in mice showed high levels of obesity in both adipose tissue and serum, and circulating protein levels correlated with obesity, markers of insulin resistance, and human CRP levels. It has been shown that lowering protein levels reduces inflammation and reduces the secretion of pro-inflammatory cytokines [29]. As a result of overexpression of ANGPTL2 in adipose tissue, inflammation is exacerbated and insulin resistance is increased. ANGPTL2 contributes to the development of inflammation also by stimulating the adhesion of leukocytes to the wall of blood vessels in the skin, increasing vascular permeability and by increasing the expression of integrins in endothelial cells, monocytes and macrophages [11, 30]. A study by Gellen et al. [31] showed a significant relationship between ANGPTL2 concentration and mortality in patients with type 2 diabetes. Thus, they confirmed the thesis that this protein, as a pro-inflammatory and pro-oxidative factor, may be the cause of the development of CVD related to type 2 diabetes.

\section{Interleukin-6 (IL-6)}

Interleukin- 6 is a glycosylated protein, a member of the $22-27 \mathrm{kDa}$ family of cytokines [15]. IL-6 is produced by fat cells, vascular stromal cells, fibroblasts, endothelial cells and myocytes. About $1 / 3$ of this cytokine is produced in adipose tissue. Adipocytes only produce about $10 \%$ of IL- 6 , the rest is produced in the cells of the adipose tissue matrix [10]. Although it has both pro-inflammatory and anti-inflammatory effects, it primarily acts as a paracrine and endocrine agent. Its effects depend on both its concentration in the serum and the place of its production and release. The synthesis and secretion of IL-6 in visceral tissue is 2-3 higher compared to subcutaneous tissue. In obese people, the concentration of this cytokine in the portal vein is significantly higher than in the peripheral blood. IL-6 stimulates the synthesis of CRP and hepatic gluconeogenesis in the liver. In peripheral tissues, this compound inhibits the expression of insulin receptors, decreases adipogenesis and secretes adiponectin $[4,18]$. Studies have shown that IL-6 reduces insulin signaling by inducing the expression of regulatory proteins from the family of cytokine signal suppressors 3 (SOCS-3), inhibiting insulin receptor autophosphorylation and reducing tyrosine phosphorylation in proteins called insulin receptor 1 (IRS-1) substrates [32, 33].

Increased SOCS3 expression has been observed in adipose tissue of obese and insulinresistant people [34]. High levels of IL-6 have been detected in unstable atherosclerotic plaque [35]. 


\section{Visfatin (nicotinamide phosphoribotransferase, NAMPT)}

Visphatin is a $52 \mathrm{kDa}$ protein that is synthesized by visceral adipose tissue [19]. It is also secreted by monocytes, lymphocytes and neutrophils [10]. Its role is to differentiate preadipocytes from adipocytes, stimulate the production of pro-inflammatory cytokines and activate leukocytes, which induce a strong pro-inflammatory effect. Visfatin exhibits a hypoglycemic effect by binding to the insulin receptor. Furthermore, this compound has been reported to be a prognostic factor for death in cardiovascular diseases [21]. Its high concentration was found in patients with acute myocardial infarction and obese patients with metabolic syndrome [36, 37]. There are studies describing the role of visfatin in acute ischemic stroke. In most cases, it has been shown that the concentration of this compound is increased in the blood of ischemic stroke patients [38, 39]. Pitoulias et al. [40] showed a correlation between high visfatin concentration and the presence and intensity of atherosclerotic lesions in peripheral blood vessels.

\section{Chemotactic factor of monocytes 1 (MCP-1)}

Hypertrophic adipocytes, especially in visceral adipose tissue, produce monocyte chemotactic factor 1 (MCP-1) [4]. This compound belongs to pro-inflammatory cytokines and shows activity that mobilizes monocytes to participate in the inflammatory process and promotes the development of the atherosclerotic process. It is produced by adipocytes and vascular stromal cells. In obese people, an increased infiltration of adipose tissue by macrophages has been observed, which secretes MCP-1, but also IL-6 and TNF- $\alpha$, which may result in an increase in insulin resistance [10]. Chipitsyna et al. [41] MCP-1 inhibits insulin receptor tyrosine kinase phosphorylation and reduces insulin-stimulated intracellular glucose transport. Moreover, by influencing the expression of genes related to adipogenesis, it inhibits the growth and differentiation of adipocytes.

\section{Interleukin-18 (IL-18)}

IL-18 is a pro-inflammatory cytokine produced by adipose tissue. The concentration of this compound in the blood serum is increased in obese subjects, but it decreases after weight loss. Furthermore, high levels of IL-18 have been detected in human atherosclerotic lesions and may indicate plaque instability. Studies in rats have shown that IL-18 overexpression leads to increased expression of endothelial cell adhesion molecules, vascular abnormalities and macrophage infiltration of the blood vessel wall [42]. In turn, cytokine deficiency leads to minor changes in a mouse model of atherosclerosis [43]. Although IL-18 is a proinflammatory cytokine, mice deficient in this compound or its receptor show hyperphagia and some features of the metabolic syndrome, including: hyperglycemia, insulin resistance and obesity [44].

\section{Chemerin}

Chemerin is a ligand of the CMKLR1 receptor (also called ChemR23 or GPCR DEZ), which is coupled with the $G$ protein and is present, inter alia, in in adipose tissue, immune cells, 
placenta, bones, lungs, and heart [45]. This compound is involved in the infiltration of adipose tissue by macrophages and in adipogenesis. Its activity can be both pro-inflammatory and anti-inflammatory and includes, among others, stimulation of the chemotaction of dendritic cells, macrophages and NK cells to inflammatory foci and reduction of the secretion of proinflammatory mediators and cytokines, including TNF- $\alpha$ and IL-6. Moreover, chemerin influences the insulin sensitivity of adipocytes and increases insulin-stimulated glucose uptake by adipose tissue [21].

\section{Plasminogen activator inhibitor (PAI-1)}

PAI-1 belongs to the family of serine protease inhibitors. It is synthesized mainly by platelets, endothelial cells and adipocytes. The synthesis of the inhibitor is stimulated by TNF- $\alpha$, TGF $\beta$, IL-1 $\beta$ and insulin. By inhibiting the tissue and urokinase plasminogen activator, it suppresses fibrinolysis. The concentration of the compound in obese people is higher, which may result in the development of cardiovascular and thromboembolic complications. Increased PAI-1 levels are considered a factor in the development of type 2 diabetes [10, 30].

\section{REFERENCES}

1. Myrda K, Rozentryt P, Nowak J, Niedziela J, Kawecka E, Poloński L. Tkanka thuszczowa w niewydolności serca - wróg czy przyjaciel? Folia Cardiol. 2010;5:232-41.

2. Murawska-Ciałowicz E. Tkanka tłuszczowa-charakterystyka morfologiczna i biochemiczna różnych depozytów. Postep. Hig Med Dosw. 2017;71:466-84.

3. Matulewicz N, Karczewska-Kupczewska M. Insulinooporność a przewlekła reakcja zapalna. Postep. Hig Med Dosw. 2016;70:1245-57.

4. Sieminska L. Tkanka tluszczowa. Patofizjologia, rozmieszczenie, róznice plciowe oraz znaczenie w procesach zapalnych i nowotworowych. Endokrynol. Pol. 2007;58:330-42.

5. Heaton JM. The distribution of brown adipose tissue in the human. J. Anat. 1972;112:35-9.

6. Gonzalez-Barroso MDM, Ricquier D, Cassard-Doulcier A-M. The human uncoupling protein1 gene (UCP1): present status and perspectives in obesity research. Obes. Rev. 2000;1:61-72.

7. Cypess AM, Lehman S, Williams G, Tal I, Rodman D, Goldfine AB et al. Identification and Importance of Brown Adipose Tissue in Adult Humans. N. Engl. J. Med. 2009;360:1509-17.

8. Wójcik B, Górski J. Brunatna tkanka thuszczowa u dorosłego człowieka: występowanie i funkcja. Endokrynol. Otyłość i Zaburzenia Przemiany Mater. 2011;7:34-40.

9. Stosio M, Witkowicz A, Kowalska A, Karabon L. Genetic background of aberrant thermogenin expression (UCP1) in obesity leading to metabolic syndrome. Postepy Hig. Med. Dosw. (Online). 2016;70:1389-403.

10. Mazur A, Matusik P, Małecka-Tendera E. Tkanka thuszczowa jako narza, wydzielania wewnętrznego. Pediatr. Pol. 2010;85:255-64.

11. Góralska M, Majewska-Szczepanik M, Szczepanik M. Mechanizmy immunologiczne towarzyszące otyłości i ich rola w zaburzeniach metabolizmu. Postepy Hig. Med. Dosw.

2015;69:1384-404.

12. Zhang Y, Proenca R, Maffei M, Barone M, Leopold L, Friedman JM. Positional cloning of the mouse obese gene and its human homologue. Nature. 1994;372:425-32.

13. Trayhurn P, Wang B, Wood IS. Hypoxia in adipose tissue: A basis for the dysregulation of tissue function in obesity? Br. J. Nutr. 2008;100:227-35.

14. Bouwman JJM, Visseren FLJ, Bouter KP, Diepersloot RJA. Infection-induced inflammatory response of adipocytes in vitro. Int. J. Obes. 2008;32:892-901. 
15. Olszanecka-Glinianowicz M, Zahorska-Markiewicz B, Magdalena Olszanecka-Glinianowicz DNM, Patofi Zjologii Śląskiego K. Otyłość jako choroba zapalna Obesity as infl ammatory disease Word count. 2008:62.

16. Xu H, Hirosumi J, Uysal KT, Guler AD, Hotamisligil GS. Exclusive Action of Transmembrane TNF $\alpha$ in Adipose Tissue Leads to Reduced Adipose Mass and Local But Not Systemic Insulin Resistance. Endocrinology. 2002;143:1502-11.

17. Reaven G, Abbasi F, McLaughlin T. Obesity, insulin resistance, and cardiovascular disease. Recent Prog. Horm. Res. 2004;59:207-23.

18. Chacińska M, Zabielski P, Grycel S, Błachnio-zabielska A. Udział kwasów thuszczowych i tkanki tłuszczowej w indukowaniu insulinooporności mięśni szkieletowych. Postep. Hig Med Dosw. 2016:1142-9.

19. Dyaczyński M, Scanes CG, Koziec H, Pierzchała-Koziec K. Endocrine implications of obesity and bariatric surgery. Endokrynol. Pol. 2018;69:574-86.

20. Saucillo DC, Gerriets VA, Sheng J, Rathmell JC, MacIver NJ. Leptin Metabolically Licenses T Cells for Activation To Link Nutrition and Immunity. J. Immunol. 2014;192:136-44.

21. Kazimierczak-Kabzińska A, Kajdaniuk D, Siemińska L, Nowak M, Głogowska-Szeląg J, Borgiel-Marek H et al. Selected adipose tissue hormones in the blood of patients with ischaemic cerebral stroke. Endokrynol. Pol. 2020;71:21-6.

22. Rajala MW, Qi Y, Patel HR, Takahashi N, Banerjee R, Pajvani UB et al. Regulation of resistin expression and circulating levels in obesity, diabetes, and fasting. Diabetes. 2004;53:1671-9.

23. Borsuk A, Biernat W, Zięba D. Multidirectional action of resistin in the organism. Postepy Hig. Med. Dosw. 2018;72:327-38.

24. Pęczek K, Nowicki M. Diagnostyka różnicowa ostrego uszkodzenia nerek. Varia Medica. 2017;1:57-64.

25. Wang Y, Lam KSLL, Kraegen EW, Sweeney G, Zhang J, Tso AW et al. Lipocalin-2 Is an Inflammatory Marker Closely Associated with Obesity, Insulin Resistance, and Hyperglycemia in Humans. Clin. Chem. 2007;53:34-41.

26. Moschen AR, Adolph TE, Gerner RR, Wieser V, Tilg H. Lipocalin-2: A Master Mediator of Intestinal and Metabolic Inflammation. Trends Endocrinol. Metab. 2017;28:388-97.

27. Law IKM, Xu A, Lam KSL, Berger T, Mak TW, Vanhoutte PM et al. Lipocalin-2 deficiency attenuates insulin resistance associated with aging and obesity. Diabetes. 2010;59:872-82.

28. Thorin-Trescases N, Thorin E. High Circulating Levels of ANGPTL2: Beyond a Clinical Marker of Systemic Inflammation. 2017. doi:10.1155/2017/1096385.

29. Ouchi N, Parker JL, Lugus JJ, Walsh K. Adipokines in inflammation and metabolic disease. Nat. Rev. Immunol. 2011;11:85-97.

30. Niedźwiedzka-Rystwej P, Trzeciak-Ryczek A, Deptuła W. Tkanka tłuszczowa i jej rola w odporności - nowe dane. Alerg. Astma Immunol. 2012;17:16-21.

31. Gellen B, Thorin-Trescases N, Sosner P, Gand E, Saulnier PJ, Ragot S et al. ANGPTL2 is associated with an increased risk of cardiovascular events and death in diabetic patients. Diabetologia. 2016;59:2321-30.

32. Mooney RA, Senn J, Cameron S, Boivin LM, Shang Y, Furlanetto RW. Suppressors of Cytokine Signaling-1 and-6 Associate with and Inhibit the Insulin Receptor A POTENTIAL MECHANISM FOR CYTOKINE-MEDIATED INSULIN RESISTANCE*. ASBMB. 2001. doi:10.1074/jbc.M010579200.

33. Ueki K, Kondo T, Kahn CR. Suppressor of Cytokine Signaling 1 (SOCS-1) and SOCS-3 Cause Insulin Resistance through Inhibition of Tyrosine Phosphorylation of Insulin Receptor Substrate Proteins by Discrete Mechanisms. Mol. Cell. Biol. 2004;24:5434-46.

34. Rieusset J, Bouzakri K, Chevillotte E, Ricard N, Jacquet D, Bastard JP et al. Suppressor of 
cytokine signaling 3 expression and insulin resistance in skeletal muscle of obese and type 2 diabetic patients. Diabetes. 2004;53:2232-41.

35. Wajchenberg BL. Subcutaneous and Visceral Adipose Tissue: Their Relation to the Metabolic Syndrome. Endocr. Rev. 2000;21:697-738.

36. Zahorska-Markiewicz B, Olszanecka-Glinianowicz M, Janowska J, Kocełak P, SemikGrabarczyk E, Holecki M et al. Serum concentration of visfatin in obese women. Metabolism. 2007;56:1131-4.

37. Lu LF, Wang CP, Yu TH, Hung WC, Chiu CA, Chung FM et al. Interpretation of elevated plasma visfatin concentrations in patients with ST-elevation myocardial infarction. Cytokine. 2012;57:74-80.

38. Ilhan N, Susam S, Canpolat O, Belhan O. The emerging role of leptin, Adiponectin and Visfatin in Ischemic/Hemorrhagic stroke. Br. J. Neurosurg. 2019;33:504-7.

39. Kadoglou NPE, Fotiadis G, Lambadiari V, Maratou E, Dimitriadis G, Liapis CD. Serum levels of novel adipokines in patients with acute ischemic stroke: Potential contribution to diagnosis and prognosis. Peptides. 2014;57:12-6.

40. Pitoulias MG, Skoura L, Pitoulias AG, Chatzidimitriou D, Margariti A, Arsenakis M et al. The role of Visfatin in atherosclerotic peripheral arterial obstructive disease. Cytokine. 2017;91:140-4.

41. Chipitsyna G, Gong Q, Gray CF, Haroon Y, Kamer E, Arafat HA. Induction of monocyte chemoattractant protein-1 expression by angiotensin II in the pancreatic islets and $\beta$-cells.

Endocrinology. 2007;148:2198-208.

42. Tan H wei, Liu X, Bi X ping, Xing S shan, Li L, Gong H ping et al. IL-18 overexpression promotes vascular inflammation and remodeling in a rat model of metabolic syndrome.

Atherosclerosis. 2010;208:350-7.

43. Elhage R, Jawien J, Rudling M, Ljunggren HG, Takeda K, Akira S et al. Reduced atherosclerosis in interleukin-18 deficient apolipoprotein E-knockout mice. Cardiovasc. Res. 2003;59:234-40.

44. Netea MG, Joosten LAB, Lewis E, Jensen DR, Voshol PJ, Kullberg BJ et al. Deficiency of interleukin-18 in mice leads to hyperphagia, obesity and insulin resistance. Nat. Med. 2006;12:650-6. 45. Stojek M. Chemeryna - rola w patologii człowieka The role of chemerin in human disease. 2017:110-7. 